\title{
Креативний академізм науково-педагогічної діяльності вченого в просторі епохи та перебігу часу. До 75-річчя академіка Кочіна Ігоря Васильовича
}

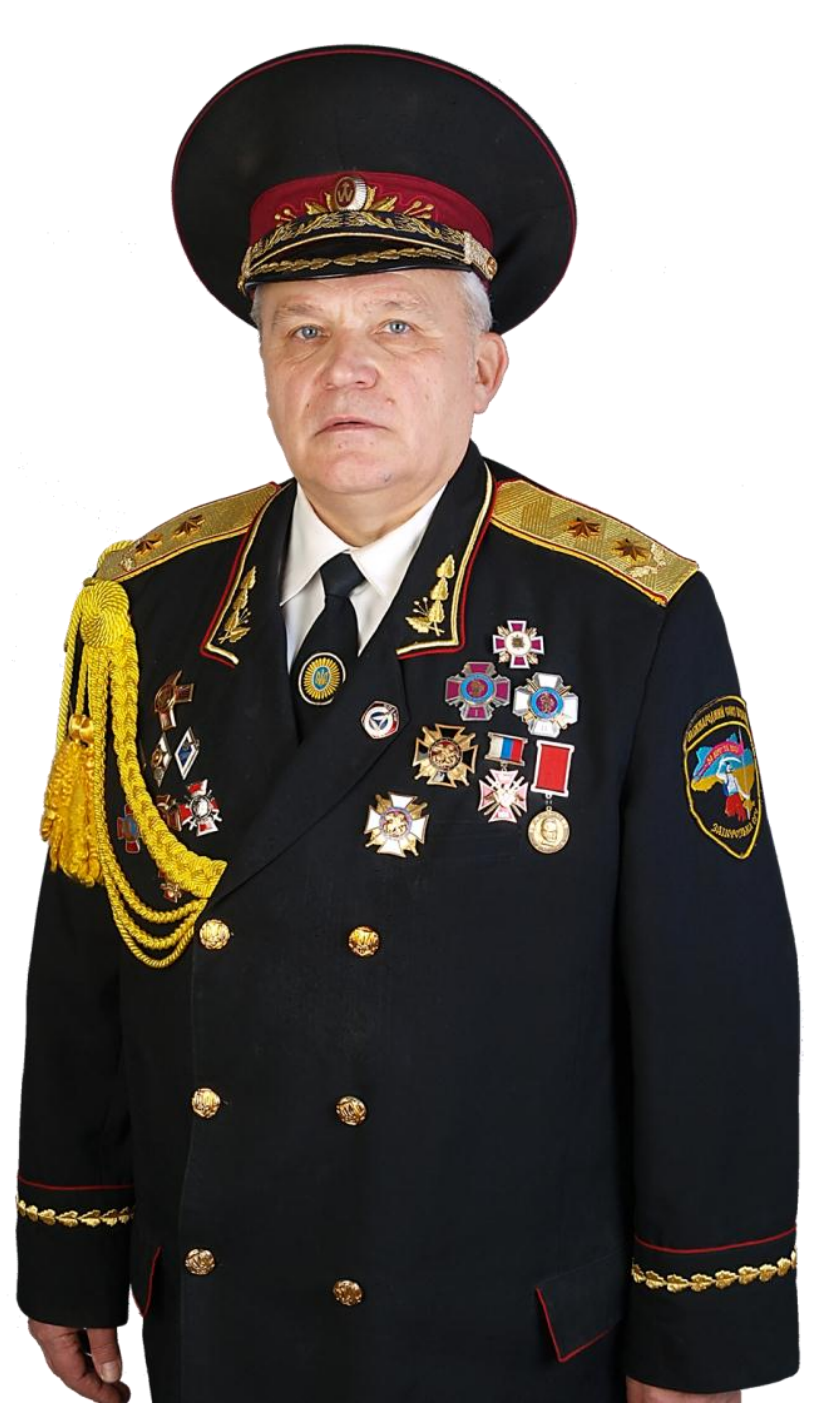

доктора медичних наук, доктора філософії, професора, академіка Української міжнародної академії оригінальних ідей, завідувача кафедри цивільного захисту та медицини катастроф Державного закладу «Запорізька медична академія післядипломної освіти МОЗ України»,

Голови науково-методичної ради з питань цивільного захисту та безпеки життєдіяльності населення Запорізької області, Заступника отамана Спілки громадських організацій «Запорозький козацький округ», генерал-хорунжого Війська Запорозького Низового

\footnotetext{
Kochin Igor Vasylyovych

Doctor of Medical Science, Doctor of Philosophy, professor, Academician of the Ukrainian International Academy of Original Ideas, Head of the Department of Civil Protection and Disaster Medicine of State Institute "Zaporizhzhia Medical Academy of Postgraduate Education of Ministry of Health of Ukraine", Chairman of the Scientific and Methodological Council on civil protection and life safety of Zaporizhzhia region, Ataman's Deputy of Nongovernmental organizations "Zaporozhye Cossacks District", General-horunzhy of "Zaporozhian Host"
}

Хто знайшов в собі духовні сили і розумові здібності
піднятися до вершин медичного Олімпу, повинен перетворитися в апостола і з інтелектуальної височини викладацької кафедри з місіонерським запалом беззавітно служити медицині. Академік Кочін I.B.
Життєпис звичайної людини обмежується цариною буденних вчинків, біографії (curriculum vitae) притаманні тільки видатним особистостям, обдарованих здібностями 3 розвиненим інтелектом, vir eruditissimus (людина найосвіченіша). Саме це визначає рівень домагань креативно працюючого вченого в сфері професійної науково-педагогічної діяльності, щоб отримати максимальний інтелектуальний ефект та уникнути творчої невдачі. Тому, науково-педагогічна діяльність це безперервний ланцюг власних інноваційних відкриттів вченого-викладача. Отже, біографія вченого - це не формальні дати про події та вчинки з життя особистості, a, в першу чергу, зміст та умови діяльності, досягнуті результати, часом всупереч об'єктивному і суб'єктивному ідеологічному, політичному, соціально-економічному та морально-духовному становищу в країні.

Вчені, на зразок академіка І.В.Кочіна, що знайшли свою мету в житті і за психологічним статусом володіють реалістичним рівнем домагань, вирізняються впевненістю в своїх розумових здібностях, наполегливістю в досягненні наукової мети, високою працездатністю, креативною плодотворністю й результативністю i, що вкрай важливо, критичним ставленням у оцінці досягнутого. Вчені духовно й інтелектуально витончені особистості у моральному сенсі та власних наукових міркуваннях, бо в них до кожної модерної креативної ідеї, судження, сприйняття і особисто створеної парадигми як сукупності філософських, загальнотеоретичних й 
спеціальних основ та теорій досліджуваної галузі науки, обов'язково долучається безмежна кількість ще додаткових філігранно проникливих уявлень, припущень, понять, неочікуваних домислів, відображень i, навіть гіпотез, що в підсумку, внаслідок творчої праці безлічі вчених впродовж багатьох століть, ефекту накопичення та синергізму знань утворюється наукова теорія - як найрозвиненіша форма наукового знання, система взаємопов'язаних понять, стверджень i доказів, що виконує всі функції наукового знання. Perspicua vera non sunt probanda (Безсумнівне немає потреби доводити).

Про видатного вченого складається суспільна думка і дається оцінка за його наукові досягнення, а не за похибки, яких він припустився в наукових пошуках. Неточності великого розуму більш повчальні, ніж судження посередності, i коли визначний науковець помиляється, то навіть своєю похибкою позначає правильний шлях науковому дослідженню, тільки в інший спосіб. Sic vita truditur (Таке життя).

Мислення одухотвореного науковими досягненнями вченого характеризується тим, що він здатний панувати над своїми думками та спрямовувати їх в необхідному напрямку, з почуттями інша справа - вони нам мало підвладні. Qui nisi sunt very, ratio quoque falsa sit omnis (Якщо почуття не істинні, то і весь наш розум виявляється хибним). Наукова діяльність так щільно уснажена різноманітними емоціями ще й тому, що в почуттях набагато більше розуму, ніж в розумі почуттів і це теж допомагає творити. Почуття, звідки не було б їх походження, спонукають до інтенсивного мислення допомагають в науковому пошуку. Самі ж думки воліють очиститися від емоцій і не заохочують вчених їх відчувати, бо заважають науковій справі.

Наукова діяльність - це завжди роздуми й пошук i для того, щоб отримати вагомий результат академік І.В.Кочін активно, креативно й наполегливо працював більше 50-ти років, при цьому його розум осяюювся авангардною парадигмою. Vivere est cogitare (Жити - це мислити). I хай кожний вчений, який здійснює наукову розвідку, не перестає відшукувати, доки не знайде відповіді. Головне полягає в тому, що науковець буде не аби як вражений отриманим результатом, який виявиться дещо відмінним від очікуваного. В цьому міститься таємниця та незбагненність наукової діяльності, бо де колись були задвірки та околиці науки тепер ії осереддя. Феномен розширення меж науки подібний до пересування обрію - при наближенні до нього, він неодмінно віддаляється 3 швидкістю тотожній наближенню і тримає науковця на незмінній відстані та перешкоджає зазирнути за краї вже відомого, зберігаючи одвічну таємницю пізнання природи, яку легше зрозуміти й пізнати, підкоряючись їй. Omne ignotum pro magnifico est (Bce невідоме здається грандіозним).

Академік І.В.Кочін своїми інноваційними судженнями намагається змістовно й найбільш повно окреслити всю проблему, що турбує світову наукову спільноту, репрезентуючи модерне уявлення про навколишній Світ і цим визначити особистий внесок у розв'язанні фундаментальної проблеми і довести власний пріоритет та інтелектуальну велич. Scientia nihil est quam veritatis imago (Знання - ніщо інше, як віддзеркалення істини). Оволодіння ідеями, судженнями, гіпотезами та теоріями геніальних людей освіченим загалом, являє собою когнітивну вправу для всієї громади, яка запліднює розум, розвиває та удосконалює свідомість всього суспільства, привчає до розмірковування in puncto puncti (в самому істотному). Мислення видатної особистості подібно Божому промислу і є творенням нової реальності. Кожний вчений - деміург, креативні ідеї якого охоплюють i визначають своїм змістом ще незнану науковою спільнотою новітню систему когнітивних уявлень, новаційну парадигму, яка в найновішому прогресивному ракурсі подає визначення наступного етапу розвитку розглядаємої проблеми, розкриваючи при цьому в наукових дослідженнях предметної області цивільного захисту та медицини катастроф (ЦЗ та МК) досягнутий рівень знань, існуюче коло проблем та перспективи їх розв'язання. На практиці це означає для академіка I.В.Кочіна осягнути суть окресленої проблематики, відтворити іiі в ідеальній формі, виявити найважливіші закономірності та зв'язки, перетворити отримані нові знання в «план» та схему реальної діяльності аварійнорятувальних бригад ДСНС та служби медицини катастроф при ліквідації медико-санітарних наслідків надзвичайних ситуацій (НС).

На переконання академіка I.В.Кочіна знанню завжди передує припущення. Значно важче досліднику побачити проблему, ніж знайти іiі вирішення. Справжній вчений добре розуміє, що для виявлення, позначення та розкриття сутності наукової проблеми потрібна фундаментальна освіта, грунтовні знання, багаторічна практична діяльність та досвід, а, ще більш вагоме, не абияка когнітивна уява й передбачення дослідника, бо вінцем науково-дослідної роботи врешті-решт $\epsilon$ завбачення іiі результатів. Вирішення ж наукової проблеми суцільно залежить вже тільки від уміння вченого розробити методолого-методичні аспекти наукової гіпотези, провідна роль якої полягає в орієнтації наукового пізнання та постановці дослідницьких завдань на основі осмислення наявного знання. Така орієнтація $\epsilon$ необхідним елементом наукової діяльності вченого, необхідним навіть у випадку, коли для формулювання наукової гіпотези не вистачає даних. Практика наукової діяльності академіка I.В.Кочіна доводить, що краще дотримуватись такої гіпотези, яка може виявитися з часом 3 певними вадами, ніж жодної. У порівнянні з науковою теорією гіпотеза менш розвинена в сенсі інтерпретацій, формального апарату тощо. Класичний випадок виникнення прогресивної гіпотези пов'язаний зі встановленням нових емпіричних даних, що не вкладаються в межі застарілих теорій. Жодна теорія не пояснює всі можливі поточні факти та отримані випробувальні результати, i завжди в дослідника $є$ достатньо більша свобода дій у визначенні того, які саме експерименти та спостереження важливі для перевірки теорій. Природній процес розвитку науки змушує вчених 3 часом переглядати задавнені наукові судження, а тому цілком слушним $є$ висловлювання геніального 
англійського вченого І.Ньютона (1642-1727 рр.) наведене у видатній науковій праці «Математичні початки натуральної філософіï» (Philosophiae naturalis principia mathematica, 1687 p.): «Hypotheses non fingo» ( $Я \mathrm{не}$ вигадую гіпотез).

Справа в тому, що сам процес наукового дослідження, який застосовується академіком І.В.Кочіним, обумовлює необхідність формування наукових припущень, висунутих вченим як попереднє, умовне пояснення будь-якого явища або процесу, що потребує перевірки у житейській реальності або досліді та подальшому всебічному теоретичному обгрунтуванні, аби перетворитися на вірогідну наукову теорію. Беззаперечно теорії базуються на достовірно встановлених фактах, але описи самих фактів повсюдно наповнені теоретичною інтерпретацією. У підсумку академіком І.В.Кочіним сформовано системне знання як відображення системної організації досліджуваних явищ або процесів, їх внутрішньої єдності та цілісності. Тобто, отримана система знань $€$ нічим іншим, як вербально-логічним аналогом реального явища або процесу. Тому будь-яка розвинена наукова теорія в предметній сфері ЦЗ та МК $\epsilon$ змістовно логічно впорядкована, ієрархічно організована система знань. Non fingendum aut, excogitandum, sed inveniendum, quid natura faciat aut ferat (Не вигадувати, не марити, а шукати, що творить і приносить природа).

Наукові гіпотези одна 3 основних форм наукового знання в сфері ЦЗ та МК, що розвивається, один з провідних засобів наукового пізнання. Будь-яка плідна гіпотеза в сфері ЦЗ та МК дає початок дивному виверженню безлічі непередбачених новацій, винаходів та відкриттів. Грунтуючись на власному досвіді академік I.В.Кочін з усіх робочих гіпотез обирав завжди ту, яка не тільки не заважала подальшому розміркуванню про явища та процеси, що досліджуються, а, навпаки, стимулювала їх на зразок проведення процедури групового креативного мислення - «мозкової атаки».

Наукова гіпотеза $є$ сходинкою при русі думки вченого від наукової проблеми до наукової теорії як вищої форми наукового знання, в просторі і часі якої перебуває дослідник все своє творче життя. Спираючись на більш як п'ятидесятирічний власний професійний науковопедагогічний досвід академік І.В.Кочін прийшов до висновку, що найбільш оптимальний критерій для об'єктивної оцінки запропонованої нової гіпотези полягає не у ii наочності, а в iï плідності, бо для розв'язання науково-теоретичної, науково-практичної та життєво важливої безпекової проблематики в предметній сфері ЦЗ та МК потрібно якомога більше креативно мислити, досліджувати та вивчати. Multi pertransibunt et multiplex erit scientia (Багато мине поколінь і різноманітна буде наука). Специфічною властивістю висунутої наукової гіпотези на переконання академіка І.В.Кочіна $\epsilon$ їі певна недостовірність, припустимий характер, з яким можливо погодитись, тобто, гіпотетичне знання має принципово ймовірну сутність. Це випливає 3 розуміння інтелектуальних особливостей технологій наукової діяльності як багатоетапного когнітивного творчого процесу пізнання, яке розпочинається з ознайомлення 3 окремими фактами, подіями, явищами та процесами 3 предметної сфери ЦЗ та МК за посередництвом почуттів та спостереження, усвідомлення зрозумілого й видимого та пізнання невидимого й утаємниченого, їх іманентних властивостей в процесі тлумачення фактів та їх взаємозв'язків. Quodcunque animus sibi imperavit, obtinet (Bсе, що поставила собі людина, вона досягне).

Згідно історичних розвідок академіка І.В.Кочіна 3 самого початку свого існування людство наражається на небезпеку, проте не здійснює належних висновків 3 вад історії існування та негативного досвіду попередніх поколінь i в гонитві за досягненнями соціальноекономічного розвитку щодалі більшою мірою робить небезпечним існування людства. Qui habet aures audiendi, audiat (Хто має вуха, почує). 3 настанням ери технічного прогресу через бездумне використання природних ресурсів постала проблема захисту довкілля і збільшення кількості та потужності природних НС. 3 подальшим розвитком технологій $\mathrm{i}$ техніки розширився спектр техногенних НC і людство почало сплачувати данину створеним технологіям, які продовжують розвиватися та урізноманітнюватися, і зупинити цей процес складно. Щомиті на Землі від впроваджених технологій, природних та соціальних НС зазнає каліцтва та гине безліч людей, яка 3 року в рік збільшується, проте незважаючи на ці величезні безповоротні та медико-санітарні втрати людство не обмежується у своїх нескінченних бажаннях будь-що задовольнити власні амбіції і невиправдані зростаючі потреби. На обгрунтовану думку академіка I.В.Кочіна людство зобов'язане збагнути, що багато чого 3 досягнутого невиправдано щодо суспільної і соціальноекономічної доцільності та споживацької достатності. Mores cuique sui fingunt fortunam (Доля наша залежить від наших норовів). Найяскравішим прикладом безвідповідального i злочинного ставлення людської цивілізації до самої себе є військові технології, які вже власне своїм існуванням спрямовані на знищення людей, а тому становлять реальну загрозу вигублення цивілізації загалом. До цього треба зарахувати проблему утилізації хімічної та ядерної зброї $\mathrm{i}$ безумовно звичайних протипіхотних мін. Multa sunt in moribus dissentanea, multa sine ratione (У людських звичаях багато незрозумілого та позбавленого здорового глузду).

Креативним дослідникам, на кшталт академіка І.В.Кочіна, які грунтуються в своїй фаховій діяльності на новітню методологію наукового пізнання, треба ретельно опанувати сукупність модерних прийомів та методів, які використовуються у науковому пізнанні Світу та практичній діяльності, шляхом адекватного багаторазового застосування. Repetitio est mater studiorum (Повторення - мати навчання). Багаторічна наукова та теоретико-методологічна діяльність академіка І.В.Кочіна доводить, що не мета освячує засоби, як стверджували єзуїти, а навпаки, методи впливають на результат, визначають і формують його, а вінцем наукової роботи $\epsilon$ довгоочікуваний передбачуваний результат. Scire proprie est rem ratione et per causam cognoscere (Усвідомлювати належним чином - означає розумітися на предметі з боку його значення та причини). 
На переконання академіка I.В.Кочіна на шляху до власного усвідомлення мети в житті першим етапом $\epsilon$ зрозуміти себе, свої потреби, здібності, а другим - активно діяти у відповідності до своїх покликань, і в такому разі буде не тільки вдалий результат наукової діяльності, а й успішно сформований в цілому життєвий шлях вченого. Важливе значення для змістовної та гідної організації особистого життя та наукової діяльності резонним $є$ грунтовне засвоєння і виконання немеркнучих у своїй актуальності думок неперевершених мудреців всіх часів i народів. Дефініції та образні вислови мислителів завдавали потужний поштовх формуванню в академіка I.В.Кочіна духовно-моральних основ особистого життя i вчили задовольнятися малим у сфері матеріальних потреб, цінувати те, чим володієш, розуміти, що, як правило, людина має найнеобхідніше, якщо ж людина не навчена цього цінувати, то ніколи не здобуде успіху в житті та науці, бо причини іiі невдач та невдоволення містяться не в довколишніх умовах та оточуючому загалі, а в ній самій. Sua cuique fortuna in manu est (Власне щастя у кожного в руках).

Батько академіка I.В.Кочіна був високоосвіченим фахівцем, у 1934 р. 3 відзнакою закінчив навчання у Ленінградському планово-фінансовому інституті, розумною, моральною й вихованою особистістю; матуся була наділена найліпшими чеснотами, виховувалася в традиційній українській селянській родині, отримала в 1934 р. медичну освіту помічника лікаря. Традиційнохристиянське виховання батьків було покладено в основу ï власного духовно-морального становлення як особистостей, які доводили своєму сину існування Бога, Вищого розуму й сили, який все створив. Відкинувши всі сумніви й заперечення щодо існування Всевишнього батьки переконували майбутнього сина-академіка у розумінні людини як творіння Божого, що має безсмертну душу, господарем якої є лише Творець.

Правила своєї поведінки людина сприймає у родині розумом і душею - крізь почуття віри, надії й любові, формує готовність відстоювати добро - в собі та навколишньому світі виходячи з усвідомлення того, що духовне начало в поведінці та вихованості людини є визначальним. Humana consilia divinitus gubernantur (Задумами людей керує воля богів). Традиційно християнське виховання в батьківській родині академіка I.В.Кочіна було глибоко просякнуте українським національним колоритом i духом - гігантська державотворча справа, пов'язана любов'ю та патріотизмом до рідної землі, і в той же час була напруженою працею для душі, бо вирішувала життєву долю. Paucis opus est litteris ad mentem bonam (Для шляхетної душі непотрібно багато науки). Виховуючи сина батьки ставили за мету сформувати самостійну особистість 3 вільною волею, протиставляючи власне розуміння особистості офіційній ідеології тоталітарного устрою радянського суспільства та сталінської системи педагогіки, в основу якої було покладено філософію бігевіоризму. Людина в системі цієї філософії трактується суто як поєднання двох чинників - генетичних особливостей організму і впливу на нього зовнішнього середовища. Per dubitandum ad veritatem pervenimus (Через сумнів приходимо до істини). Теорія бігевіоризму відповідала глобальним цілям радянської влади, коли навчальні заклади всіх рівнів наставляли і виховували народ відповідно до потреб тоталітарного режиму, а, саме, формували викривлену свідомість та спотворений світогляд в населення СРСР пристосовані для існування в умовах недемократичного устрою суспільства. Заперечуючи автономію особистості в зовнішньому середовищі та у вихованні, не визнаючи фактично свободу вибору i гідності людини, авторитарний радянський режим призводив до формування «людини колективної», зумовлював становлення «комунального мислення» - в основі своїй безвідповідального. Кожна людина в СРСР потрапляла під закон стандартизації і перетворювалася на той самий горезвісний «гвинтик» соціальної будови. Християнство відкидає поняття «колективної» людини. Характерний для марксизму культ «класу», «трудового колективу» втілює в собі ідею загальної безвідповідальності, стихію розбещеного зла і не сприяє креативному розвитку особистості. Suum malum cuique (Кожному своє зло).

Очевидно, що в контексті подібних поглядів людина відчуває себе «випадковою» і «загубленою» в космічному бутті, позбавленою будь-чиєї опіки, а з іншого боку, - ніким не керованою і нікому не підзвітною. Статус iii - не визначений. Людина може трактуватися і як цар природи, і як бидло. Носієм аморальності виступає людина безлика, що ховається за «масу», за «колектив», як справжній злодій - у натовпі. Така істота робить зло і тут же заявляє: «У цьому не моя провина - така воля колективу». Nemo potest personam diu ferre (Ніхто не може довго носити маску).

В родині, яка сповідує християнські цінності, природно формується мудрість і праведність - від Бога, моральність, сумління і справедливість - від батьків, вченість і розсудливість - від істини. Головним завданням батьків майбутнього академіка I.В.Кочіна було призвичаїти сина самостійно мислити, гідно й розумно вирішувати проблеми життєвого вибору, через який реалізується свобода особистості і передбачуваність наслідків вчинків. Саме в такій родині виховувався академік І.В.Кочін, батьки якого надавали йому найпорядніші життєві уроки та приклади гідної поведінки в суспільстві. Dos est magna parentum virtus (Доброчесність батьків - великий посаг). Освічена й креативна особистість - це завжди родинний скарб і безцінний суспільний капітал.

Життєвий шлях академіка I. В. Кочіна розпочався у славетному козацтвом місті Запоріжжі у родині інженераекономіста, ветерана Другої світової війни Василя Івановича Кочіна (1904-1976) та медичного працівника Валентини Андронівни Кочіної (Палієнко) (1914-2005) 26 серпня 1945 р. Упродовж 1952-1963 рр. він вчиться у Запорізькій загальноосвітній трудовій політехнічній школі № 65 із виробничим навчанням і активно займався спортом. В 1963 p. поступив на навчання до Дніпропетровського медичного інституту, в якому навчався два роки, а на третій курс був переведений до 
Запорізького медичного інституту, який закінчив в 1969 p. Молодому спеціалісту було запропоновано працювати на посаді асистента кафедри соціальної гігієни та організації охорони здоров'я, займатися педагогічною та науковою діяльністю. Під керівництвом завідувача кафедри соціальної гігієни та організації охорони здоров'я Дніпропетровського медичного інституту, заслуженого працівника вищої школи УРСР, д.мед.н., проф. Г.Ф. Смельянової виконав та в 1982 р. захистив кандидатську дисертацію «Социально-гигиенические аспекты состояния здоровья рабочих некоторых коксохимических предприятий Украины».

У 1983 р. кандидат медичних наук І.В.Кочін був запрошений на науково-педагогічну роботу до Запорізького державного інституту удосконалення лікарів, в якому почав працювати з 20 червня 1983 р. на посаді старшого викладача кафедри соціальної гігієни та організації охорони здоров'я і продовжував активно займатися науково-педагогічною роботою. За активну педагогічну, навчально-методичну та наукову роботу, принципово нові наукові результати досліджень впливу образу, способу та стилю життя на формування стану здоров'я працівників промисловості, успішне завершення докторської дисертації рішенням Вченої ради ЗДІУЛ від 15 листопада 1994 р. Ігорю Васильовичу присвоєне вчене звання доцента. Збагачення сучасної соціальної медицини працями першорядного наукового значення, створення нового наукового та практичного напрямку, сучасної теорії і запровадження ії у практику, стало грунтовною основою обрання I.В. Кочіна 16 жовтня 1993 р. академіком Української міжнародної академії оригінальних ідей.

У 1996 р. захистив докторську дисертацію на тему «Наукове обгрунтування соціально-гігієнічних аспектів системи збереження і відтворення стану здоров'я працівників промисловості (на прикладі коксової i хімічної промисловості)». У 2006 р. І.В.Кочіну було присвоєно вчене звання професора. В комплексному дисертаційному дослідженні були розроблені нові теоретико-методологічні та методичні парадигмальні основи системи «Образ, спосіб та стиль життя - здоров'я», що відповідало практичним потребам держави $\mathrm{i}$ суспільства. Учений створив сучасну теорію соціальногігієнічної сфери образу, способу та стилю життя, на основі якої розроблені змістовно взаємопов'язані їх концептуальна, логічна та операціональна моделі. Для опису і пояснення логіки соціальної взаємодії у науковий обіг соціальної гігієни (медицини) та практичного використання у діяльності державної системи забезпечення збереження та відтворення стану здоров'я української нації академік I. В. Кочін увів системну діалектичну тріаду понять - образ, спосіб та стиль життя, - які переходять одне в одне і віддзеркалюють діалектику соціальних процесів на різних рівнях узагальнення, розкриваючи їх формуючий вплив на стан здоров'я, а звідси змістовне розуміння механізму формування здорового образу, способу та стилю життя. Causarum cognitio cognitionem eventorum facit (Пізнання причин призводить до пізнання наслідків).
Ці наукові розробки стали фундаментальною основою розв'язання проблеми практичного оцінювання образу, способу та стилю життя особи, що сприяло вирішенню давньої нагальної проблеми держави та суспільства зі створення, впровадження та прогнозної оцінки ефективності конкретних державних програм, соціальних і медико-соціальних заходів із суттєвого підвищення стану та потенціалу здоров'я населення України через покращення функціонування систем життєзабезпечення, які обумовлюють стан здоров'я, християнське виховання, духовний й морально-етичний рівень суспільства, формування та підтримку здорового образу, способу та стилю життя. Академіком І.В.Кочіним математично коректно доведено об'єктивне існування відмінних якісно та неповторних змістовно особистих образів, способів та стилів життя в кожного індивіда, які й визначають стан і потенціал здоров'я, формують особисту патологію, можливість (ймовірність, ризик) виникнення та фактичне виникнення окремих нозологій у кожної особи. Академік І.В.Кочін довів, що образ, спосіб та стиль особистого життя регулюється і залежить від власної системи духовно-етичних цінностей, які, своєю чергою, формуються під впливом панівних у державі й суспільстві еталонів моральності і свідомості. Глибокий науковий аналіз людського існування (повсякденної життедіяльності) у дослідженнях вченого здійснив вирішальний поштовх у використанні надбань філософії екзистенціоналізму для вивчення соціально-гігієнічних проблем системи «Образ, спосіб та стиль життя здоров'я». 3 досліджень Ігоря Васильовича випливає фундаментальний висновок, що саме ігнорування цієї сфери владою неодноразово було причиною серйозних кризових ситуацій у суспільстві, в той час, як пильна увага до них у західній цивілізації рятувала ії від соціальних катаклізмів, зокрема й у сфері здоров'я, бо необхідною умовою оптимального функціонування і розвитку будьякої суспільної системи, яка забезпечує збереження i відтворення здоров'я нації, $є$ реальне впровадження ії принципів в повсякденне життя населення. Філософія екзистенціоналізму має справу не 3 чисто науковими проблемами, а з проблемами власне людського існування, морально-етичної рефлексії людини, а тому може бути покладена у теоретико-методологічну основу наукових фундаментальних й прикладних соціально-гігієнічних досліджень. Заслуга екзистенціоналізму при використанні його наукових надбань у сфері соціальної гігієни полягає в тому, що ця філософія звертається до людини як до суб'єкта автономно-кзистенціального повсякденного життя. Філософія повинна повернутися до людини, до іiі повсякденних проблем, допомогти їй знайти зрозумілу істину, заради якої людина могла б жити, допомогти иій зробити внутрішній вибір і усвідомити своє «Я».

312 березня 1998 р. академік І.В.Кочін очолює кафедру цивільного захисту та медицини катастроф ДЗ «Запорізька медична академія післядипломної освіти МО3 України». 3 цього часу основним науковим напрямом його роботи є розробка організаційних та управлінських засад, планування, інформаційного та матеріально-технічного 
забезпечення діяльності Державної служби медицини катастроф (ДСМК) України, організації надання екстреної медичної допомоги населенню, потерпілому від надзвичайних ситуацій. Так, у наукових працях Ігоря Васильовича міститься велика кількість принципово нових ідей, понять та підходів до розв'язання актуальних проблем науки i предмету викладання: цивільного захисту, медицини катастроф, організації та надання екстреної медичної допомоги при НС, які розвиваються науковою школою.

В зв'язку 3 цим наукова робота професорськовикладацького складу кафедри ЦЗ та МК під керівництвом академіка I.В.Кочіна була спрямована на виконання низки наступних науково-дослідних робіт: «Організація надання екстреної медичної допомоги ураженим сильнодіючими отруйними речовинами (СДОР) в догоспітальному періоді» (1996-1999рр.), «Організація захисту працівників хімічно небезпечного об'єкта при аваріях на ємностях з сильнодіючими отруйними речовинами» (2000-2003рр.), «Організація екстреної медичної допомоги працівникам хімічно небезпечного об'єкту при аваріях на ємностях 3 хлором» (2004-2006 рр.), «Організація та планування екстреної медичної допомоги Державною службою медицини катастроф територіального рівня працівникам та населенню у разі виникнення осередків ураження при аваріях на хімічно небезпечних об'єктах» (2007-2011рр.), «Удосконалення організації та діяльності Державної служби медицини катастроф України при наданні екстреної медичної допомоги у надзвичайних ситуаціях» (2012-2016 рр.), «Удосконалення планування і організації діяльності Служби медицини катастроф 3 надання екстреної медичної допомоги при надзвичайних ситуаціях мирного та воєнного часу» (2017-2021 рр.).

Починаючи з 1998 р. академіком І.В.Кочіним було створено декілька творчих авторських колективів для підготовки 39 підручників та навчальних посібників. Він $€$ автором понад 800 наукових праць, що складають основу для створення сучасного досконалого науково-виробничодовідкового багатотомного керівництва 3 медицини катастроф.

З 1999 р. академік І.В.Кочін є Головою науковометодичної ради з питань цивільного захисту та безпеки життєдіяльності населення Запорізької області, яка визнана Державною службою України 3 надзвичайних ситуацій кращою в країні.

Академік І.В.Кочін за материною лінією походить 3 українських козаків, які заповідали берегти Хортицю, Запорожжя, свої сонячні степи. Проводить важливу роботу з розбудови козацтва України, є генерал-хорунжим Війська Запорозького Низового, заступником отамана 3 роботи 3 особовим складом Спілки громадських організацій «Запорозький козацький округ».

Людину пізнають за справами, а у продуктивній корисній для суспільства праці є сенс особистого життя.

Національна академія наук України

Національна академія медичних наук України

Українська військово-медична академія

Українська міжнародна академія оригінальних ідей

ДЗ «Запорізька медична академія післядипломної освіти Міністерства охорони здоров'я України»

Кафедра цивільного захисту та медицини катастроф ДЗ «ЗМАПО МОЗ України»

Науково-методична рада $з$ питань цивільного захисту та безпеки життсдіяльності населення Запорізької області щиро вітають 3 ювілеєм і бажають подальших успіхів у служінні науці і практиці медицини.

Дата надходження рукопису до редакції: 03.01.2020 p.

Примітка. У статтях збережено орфографію, пунктуацію та стилістику авторів. 